\title{
Analysis of Risk Factors HIV/AIDS Transmission Caused By Sexual Intercourse and Use of Syringe in Aceh Province
}

\author{
Masriyani $^{1}$, Mudatsir ${ }^{1}$ and Nizam Ismail ${ }^{2}$ \\ ${ }^{1}$ Magister of Disaster Science. Syiah Kuala University \\ ${ }^{2}$ Medical Department, Faculty of Medical, Syiah Kuala University \\ ${ }^{2}$ Public Health Department, Medical Faculty, Muhammadyah University \\ \{masriyani1983@gmail.com\}
}

\begin{abstract}
HIV/AIDS is a threat to health disasters. The increase in the epidemic was very rapid in developing countries such as Indonesia, including Aceh Province. Transmission through sex, the use of the syringe, blood transfusions and transmission of mother to child. This study only analyzed the risk factors for transmission due to sex and the use of a contaminated syringe. Characteristic factors also play a role: age, gender, religion, marriage, education, employment, income, and ethnicity. Design research analytic survey with a cross-sectional method with 74 samples out patient treatment RSUDZA uses Slovin techniques. An analysis p rogram data through SPSS 23.0 for linear regression. The results show the characteristic factors that are vulnerable: groups of 31-45 years old, male, married, Muslim, non-working, laborers, entrepreneurs, scholars, income below the regional minimum wage and other tribes. Regression results showed a significant relationship at $95 \%$ confidence level, sexual intercourse $(p=0,0001)$, syring use $(p=0,0001) . R^{2}$ value $=59.6 \%$ with the contribution of the use of contaminated syringes by $39.8 \%$ more dominant than the sex of $19.8 \%$ in the risk of transmission of HIV/AIDS in Aceh Province. Risk factor sexual intercourse include sex with an official partner and even free sex, a lack of knowledge about partner health, especially related to HIV / AIDS, lack of awareness of condom use and has a hospital chart of PMS. Risk factors for syringe use include the used syringe of alternately in drugs and treatment.
\end{abstract}

Keywords: HIV/AIDS, Sexual Intercourse, Use of the syringe

\section{Introduction}

HIV/AIDS like an iceberg as it's infectious, deadly, and its height stigma of the community towards HIV/AIDS sufferers and their families so as to lead to discriminatory treatment in work, medicine, care, education and so on. In the epidemic disaster management cycle, this disease is included in the situation where there is no disaster, including prevention and mitigation activities related to effective and efficient prevention, control and eradication efforts. Statistics on HIV/AIDS cases in Indonesia cumulatively HIV/AIDS since 1 April 1987 until 30 September 2014 amounted to 150,296 cases of HIV, and 55,799 cases of AIDS and 9,796 cases of death [1] recorded cumulatively HIV / AIDS cases as many as 389 cases. VCT clinic administration Aceh Province in RSUDZA HIV cases until July 2015 amounted to 286 cases. These numbers are quite alarming, where the number of people with HIV / AIDS in Aceh Province has reached $0.2 \%$ of all HIV/AIDS sufferers in Indonesia. The development of these data shows that the Province of Aceh risk of experiencing an endemic disaster at future. Some risk factors for 
transmission of HIV / AIDS through sexual intercourse, blood transfusion, mother to child transmission, and the use of alternating syringe [2]. Studies of the risk factors for HIV/AIDS transmission, especially as a result of sex and the use of the syringe, are considered very high important as material knowledge and education so disaster prevention can be done well and efficiently. Therefore it is necessary to do research on "Analysis Of Risk Factors HIV/AIDS Transmission Caused By Sexual Intercourse And Use Of Syringe In Aceh Province".

\section{Research Methods}

The study was conducted at the Voluntary Counseling and Testing clinic Zainoel Abidin Regional General Hospital (VCT RSUDZA ) in Aceh Province from 18 to 31 May 2018. The research design is a survey that is analytically based cross-sectional with multiple linear regression methods. The sampling technique is Non-Random Sampling ) Accidentally by using Slovin formula as the following [3]:

$$
\mathrm{n}=\mathrm{N} /\left(1+\mathrm{Ne}^{\wedge} 2\right)
$$

n: Sample size/number of respondents, N: Population size, e: Percentage of allowance for accuracy of sampling errors that can still be tolerated where $\mathrm{e}=0.1$. that can still be tolerated where $\mathrm{e}=0.1$

$\mathrm{n}=286 / \llbracket 1+286(0,1) \rrbracket \wedge 2$

$\mathrm{n}=286 / 3,86$

$\mathrm{n}=74,09$ (adjusted by the researcher)

The analyzed data is primary data obtained from instruments in the form of a questionnaire. Recapitulation of respondents' answers was tabulated with Ms. Excel for the process of analysis, discussion, and conclusions. The first step in multiple linear regression analysis is the classical assumption test. After the test is fulfilled, the multiple linear regression analysis can be done through the SPSS 23.0 program with regression equations [4] as follows:

$$
\mathrm{Y}=\alpha+\beta 1 \mathrm{X} 1+\beta 2 \mathrm{X} 2+\mathrm{e}
$$

$\mathrm{Y}=$ HIV/AIDS, $\mathrm{A}=$ Constants, $\mathrm{X} 1=$ Sexual Intercouse, $\mathrm{B} 1=$ coefficient regression of variable $\mathrm{X} 1, \mathrm{X} 2=\mathrm{Use}$ of contaminated syringe/drugs Injections, $\beta 2=$ Regression coefficients of variable $\mathrm{X} 2, \mathrm{e}=$ Standard error . Next is the $\mathrm{t}$ test (Partial) and $\mathrm{F}$ (A nova ) tests , Determination Coefficients $\left(\mathrm{R}^{2}\right)[5]$ to assess the properness of the equation.

\section{Research Results}

The highest age of HIV/AIDS characteristic patients is at the age of 36 years to 40 years as many as 20 people $(27.0 \%), 41$ years to 45 years as many as 16 people $(22 \%)$, and 31 years to 35 years as many as 14 people $(19 \%)$. Thus, it can be seen that the age category is vulnerable to HIV/AIDS is 31 years to 45 years which is productive age. The number of male patients as many as 65 people $(88 \%)$ very dominant than females 9 people $(12 \%)$. This is in line with previous research by Fahdhienie \& Desvita [6] identified that men were more infected with HIV/AIDS (65\%) than women (35\%).

The patient of HIV/AIDS in Aceh Province 93\% came from Muslims. This is in accordance with the statistical data on the number of the Muslim population in Aceh Province, namely above $90 \%$ [7]. A person's religious status does not guarantee that he is not infected with 
HIV/AIDS if it is not aligned with behavior (morals) in implementing religious guidance. In essence, all existing religious teachings in the world demand their people behave well and be clean and even holy. So that the high number of people with HIV/AIDS from Muslims can be linked to activities that violate the provisions of religion and norms by their followers.

Furthermore, HIV/AIDS sufferers with a married status 44 people $(60 \%)$ are the highest group compared to unmarried status as many as 18 people $(24 \%)$ and those widow/widower status as many as 12 people (16\%).Similarly, the religious factor, married status is also not a guarantee to protect the epidemic of contracting HIV/AIDS. Possibly affected by other factors.

When connected with characteristic respondents by education, most of the sufferers were identified in undergraduate education at $35.1 \%$ (26 people), followed Senior high school is $31.1 \%$ (23 people), junior high school is $25.7 \%$ (19 people) and elementary school is $8.1 \%$ (6 people). Theoretically, the higher level of education will influence a person's behavior patterns in taking a better policy. However, the results of the study show that high education is directly proportional to the level of HIV/AIDS risk transmission. This thing explains high education, the pattern of one's life becomes worse, which is evidenced by the number of HIV/AIDS.

High Education support decent jobs with earnings sufficient. Conversely, high education does not necessarily also get a decent job and income. From the number of respondents who have income below the regional minimum wage is obtained that has a bachelor status and works as an entrepreneur. It shows that high education with occupation entrepreneurs do not ensure have a better income. Aceh suffered as much as $32.4 \%$ with entrepreneur employment, the unemployment group of $20.3 \%$, the labor group of $18.9 \%$. The group with the type of work as civil servants is the lowest HIV/AIDS group of $12.2 \%$.

Types of work proved to affect people's susceptibility to HIV/AIDS. This can be explained by one's lifestyle which is very closely related to work with income. If an entrepreneur is considered a high- income person or higher than the regional minimum wage and otherwise a worker is considered a low- income person or below the regional minimum wage, then the phenomenon that appears is very interesting. High income triggers a person with a free, unlimited lifestyle, and vice versa low income makes people behave apathetically which also leads to a bad lifestyle.

Suffers from income below the regional minimum wage as many as 39 people $(52.7 \%)$. They are thought to be an accumulation of people with HIV/AIDS who are unemployed, laborers, and private employees. Whereas sufferers with income higher than regional minimum wage as many as 23 people $(31.1 \%)$. This explains both incomes that is higher than the regional minimum wage nor the earnings below the regional minimum wage has a chance of infection of HIV/AIDS. With income higher than regional minimum wage can encourage someone to do many things that can change their healthy lifestyle especially related to sex. Where only by relying on money then it's easy can get something, you want especially related to deviant behavior. As for people who earnings lower than regional minimum wage, did not rule out the conditions for low income and the level of faith that is lacking it will most likely lead to a pattern of behavior that is not good for getting income much more than or in other words, can fall into sex with background want to get money.

Suffers infected with HIV/AIDS in Aceh Province identified mostly came from other tribes by $41 \%$ (30 people). One of the factors that favor the spread of the epidemic $\mathrm{k}$ HIV/AIDS is a population migration activity for various reasons such as work and marriage. By chance, this research was conducted in Aceh. Therefore, a small portion of the Acehnese is identified with the status of HI /AIDS. It can be explained that the HIV/AIDS epidemic in Aceh Province has spread to evenly distributed ethnic groups. Aceh's specialty in the field of religion and culture 
is not a guarantee for the formation and a healthy and good lifestyle. This requires the attention of all parties to be able to carry out HIV/AIDS disaster mitigation efforts.

\subsection{Sexual Intercourse}

Sexual behavior related to the transmission of HIV/AIDS in Aceh Province was analyzed from questionnaire questions number 1-10 given code P1-P10. The results of the study can be seen in Figure 3.1.

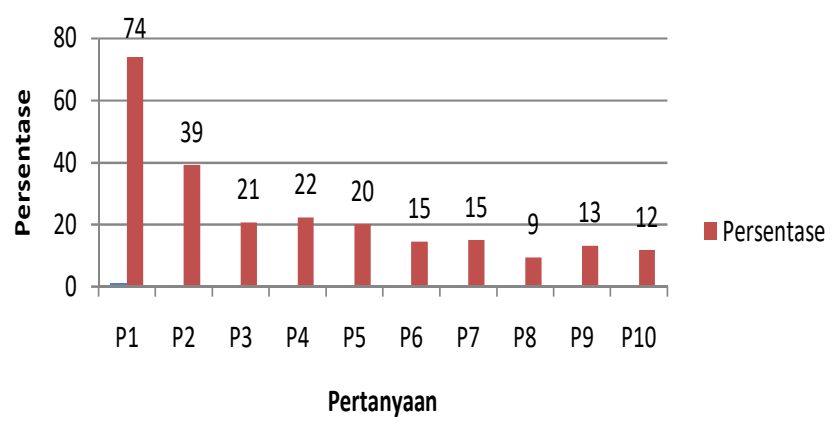

Figure 3.1 Percentage of Respondents' Answers Regarding Sexual intercourse $(n=74)$

Based on Figure 3.1, a total of 74\% (55 people) with HIV / AIDS in Aceh Province had had sexual intercourse $(\mathrm{P} 1)$, or in other words, as many as $26 \%$ of respondents have never had sexual intercourse. This correlates with the characteristics of marital status, of which $76 \%$ are married to HIV / AIDS and $24 \%$ of respondents are unmarried.

HIV/AIDS sufferers those who only had sex with an official partner (P2) amounted to 29 people $(39 \%)$. When associated with the analysis of the previous question (P1), almost $50 \%$ of patients who have had sexual intercourse or are married make a statement that they only have sexual intercourse with an official partner. In other words, there are $50 \%$ of people with HIV/AIDS who have relationships with informal partners.

Furthermore, in the third question (P3), the frequency of frequent sexual intercourse is recognized by only $21 \%$ of people with HIV/AIDS. It can be explained that more people with HIV/AIDS who have a frequency rarely have sex with their partners $(31 \%)$. This reflects the problem of harmonization in the household which leads to a low level of partner sex. This disharmonization can then produce new problems such as deviant sexual behavior or drug use.

Disharmonization is also shown by the fact that only $22 \%$ of people with HIV/AIDS know their partner's health condition (P4) in general. Here there is a phenomenon of apathy towards the couple, which is not considering the health of their partner by $31 \%$. When continued with the question whether you know that your partner has HIV/AIDS (P5), only $20 \%$ of people with HIV/AIDS know that their partner also has HIV/AIDS. In this case, 33\% of HIV/AIDS sufferers did not know their partner's HIV/AIDS status. This incident is quite natural because an HIV/AIDS sufferer tends to want to keep his health status secret in regard to feelings of shame and worry about getting social sanctions such as mistreatment or even being abandoned by his partner.

The results of the study on the question ( P6 ) show that $15 \%$ of people with HIV/AIDS also engage in sexual intercourse with unofficial partners. The quality of this relationship is worse 
with the condition of the level of knowledge of HIV/AIDS sufferers towards unofficial partner health (P7) lower (15\%) and conversely, the level of knowledge of HIV/AIDS sufferers on unofficial HIV/AIDS status (P8) is also lower, namely $9 \%$. While the frequency of sex with an unofficial partner (P9) ranges from 13\%. These results can be correlated with the status of the implementation of Islamic law in Aceh Province where the condition of the people is still more controlled compared to the conditions of the people in other big cities such as Medan and Jakarta. It can be said that the possibility of having sexual intercourse with an informal partner in Aceh Province is relatively low.

Regarding the technique of safe sexual intercourse, only $12 \%$ of respondents want to use a condom for their sexual activities. Apart from the existence of a free condom provision program at government health service. This can be attributed to low income so that it is unable to fulfill condoms that have to pay more.

\subsection{The Use of Contaminated Syringes}

The behavior of using contaminated syringe related to the transmission of HIV/AIDS in Aceh Province was analyzed from questionnaire questions number 1-10 given code P 1 1-P1 2. The results of the study can be seen in Figure 3.2.

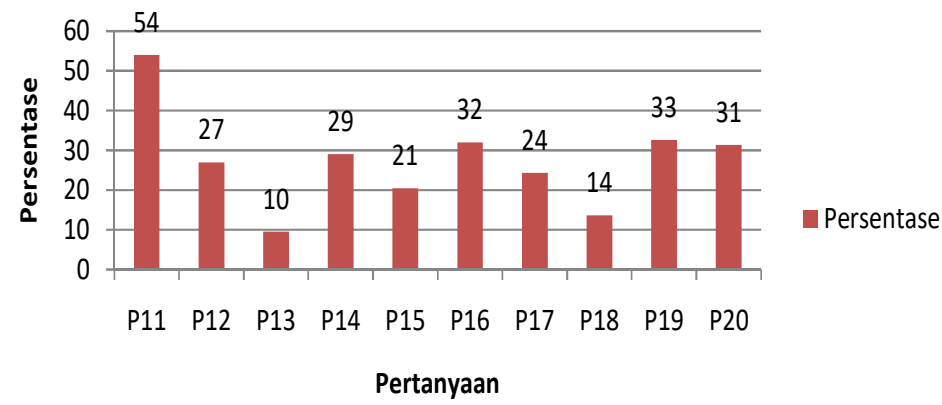

Figure 3.2 Percentage of Respondents' Answers Regarding the Use of Syringes Polluted $(\mathrm{n}=74)$

Based on Figure 3.2, as many as 40 people (54\%) with HIV/AIDS in Aceh Province are drug users (P11). In other words, $46 \%$ are not drug users. This can be correlated with the high rate of HIV/AIDS sufferers of the male sex, where men have a greater potential to use drugs compared to women. In question P12, 27\% of people with HIV/AIDS admitted that they had used a contaminated syringe, but some said they did not use a contaminated syringe. The cause of the use of a contaminated syringe is because only $10 \%$ of people with HIV/AIDS have personal syringe supplies (P13). This means that $40 \%$ of people with HIV/AIDS do not have personal syringe supplies. As a result of the low ownership of syringe equipment, $47 \%$ of people with HIV/AIDS used this syringe alternately (P14) with a frequency level (P17) of $24 \%$. This is where the chance of contracting HIV/AIDS can be seen because alternating use is a critical point of HIV/AIDS transmission. The use of shared syringes when treatment (P15) is low, which is only $16 \%$ with a frequency of $14 \%$ (P18). This can be attributed to the level of knowledge of HIV/AIDS sufferers on the transmission of this disease through the use of a contaminated 
syringe (P16) which was low by $32 \%$. The low level of ownership of personal syringe equipment can be attributed to low income where the majority of HIV/ IDS sufferers (52\%) earn below regional minimum wage.

Furthermore, HIV/AIDS sufferers felt that they were infected through the use of a contaminated syringe (P19) of 33\%. As many as $31 \%$ of people with HIV/AIDS claimed to have had blood contact through the use of tools before they realized that they had HIV/AIDS (P20). This can be attributed to the previous question, namely P16 about their knowledge of HIV/AIDS transmission through the use of a contaminated syringe. It can be said that all people living with HIV / AIDS who know about the risk of transmission of HIV/AIDS through the use of contaminated syringes and already become drug users assume that they are infected with HIV/AIDS through this factors.

\subsection{Risk of HIV / AIDS Transmission}

Each Risk factors for HIV/AIDS transmission in Aceh Province were analyzed from 10 questions coded P21-P30. The results of his research can be seen in Figure 3.3.

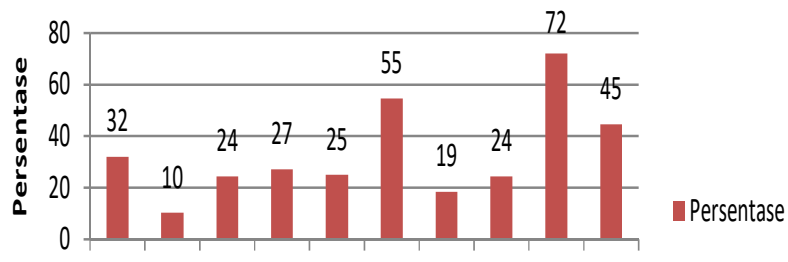

$\begin{array}{lllllllllll}\text { P21 } & \text { P22 } & \text { P23 } & \text { P24 } & \text { P25 } & \text { P26 } & \text { P27 } & \text { P28 } & \text { P29 } & \text { P30 }\end{array}$

Pertanyaan

Figure 3.3 Percentage of Respondents' Response to HIV / AIDS ( $\mathrm{n}=74)$

Based on Figure 3.3, people with HIV/AIDS who have a history of previous sexually transmitted diseases (P21) amounted to 24 people (32\%). Then only $10 \%$ of people with HIV/AIDS were examined by a doctor regarding the sexually transmitted disease (P22). HIV/AIDS sufferers who know the early symptoms of HIV/AIDS (P23) are 76\% while those with HIV/AIDS who know the acute symptoms of HIV/AIDS (P24) are $85 \%$. This is understandable because early symptoms of HIV/AIDS are more difficult to know compared to acute symptoms. The level of knowledge of people with HIV/AIDS on early and acute symptoms shows that knowledge of people with HIV/AIDS about this disease is quite good. Moreover, this can be correlated with the level of education of HIV/AIDS sufferers dominated by scholars. The same is confirmed by the question P25, that $78 \%$ of people with HIV/AIDS know about their immune paralysis due to the HIV virus attack. As many as $72 \%$ of people with HIV/AIDS have examined their health before seeing that they have contracted HIV/AIDS (P26). This reflects the results of the attack of the HIV virus on the body's immunity which causes sufferers of HIV/AIDS early symptoms often feel unwell.

HIV/AIDS is a frightening assumption in society. In question P27, as many as $58 \%$ of people with HIV/AIDS stated that their status was known to the community around their residence. As many as $76 \%$ of people with HIV/AIDS stated that their families knew their status (P28). This 
has become very important, which shows that there is great support from the family for subsequent HIV/AIDS sufferers.

The risk of transmission of HIV/AIDS has been realized by $95 \%$ of people with HIV/AIDS (P29). This number is quite high. However, the government must not ignore the $5 \%$ of people with HIV/AIDS who do not know the risk of HIV/AIDS transmission properly. Awareness of the risk of transmission of HIV/AIDS has to it reach $100 \%$, where both people with HIV/AIDS or another person can be saved by this knowledge.

The impact in terms of life so s ial, 77\% of people with HIV / AIDS began to limit the association of their social community. This can be understood as a result of feeling embarrassed or worried about getting scorn and stigma from the community. However, increasing knowledge that the opportunity and the right to life of people living with HIV/AIDS are the same as other people need to continuously campaign. HIV/AIDS sufferers are not community trash, but are part of the community. Especially passive HIV/AIDS sufferers who are infected from their official partners, children who are infected from their mothers, people who are infected by transfusions and so on.

\subsection{Factor Analysis of HIV/AIDS Transmission in Aceh Province}

The results of the analysis of multiple linear regression models for risk factors for transmission of HIV / AIDS could be written with the equation:

$$
\mathrm{Y}=0,909+0,452 \mathrm{X} 1+0,487 \mathrm{X} 2
$$

Based on these equations can be explained that the value of 0.909 is the value of a constant or an intercept value that shows the value $\mathrm{Y}$ when $\mathrm{X} 1$ and $\mathrm{X} 2$ do not exist. Increase in the number of $\mathrm{X} 1$ as many as 1time will increase the chance of HIV/AIDS transmission by $45.2 \%$. Likewise, the increase in the number X 21 time will increase the risk of HIV/AIDS transmission by $48.7 \%$. To obtain more accurate data or test the feasibility of multiple linear regression equations, 3 (three) tests are carried out, namely: First, the t-test where the variable free (X 1 and $\mathrm{X} 2$ ) in Parsia 1 significant effect on the risk of HIV/AIDS transmission. With the value of $t$ count $>1.993$ and $p$-value $<0.05$. In other words, an alternative hypothesis can be accepted. Second, F test where the variable free (X 1 and $X 2$ ) simultaneously have a significant effect on the dependent variable $(\mathrm{Y})$. $\mathrm{N}$ use values $\mathrm{F}$ count $>3.13$ and $\mathrm{p}$-value $<0.05$. In other words, alternative hypotheses can be accepted. Third, R-square value of $0,596(59.6 \%)$ means that there are $59,6 \%$ the contribution of sex factors and the use of syringes that were contaminated with risk factors for HIV/AIDS transmission while $40.4 \%$ were influenced by other risk factors not examined in this study. The use values $r$ at 0,772 meaning "strong". the contribution of each variable was described using Beta coefficient for sex at 0.406 and syringe use at 0.604 . The $r$ value of sex is 0.489 and syringes are 0.660 with p-value of 0.0001 that is: First, the contribution of variable sex which is $0.489 \times 0.406=0.198534$. Second, the contribution of injectable needle variables is $0.660 \times 0.604=0.39864$. Third, the contribution of both is 0.59717 or rounded to 0.597 (R - square). Thus, a more dominant contribution to the risk factors for transmission of HIV/AIDS in Aceh Province is the use of contaminated syringe of $39.8 \%$ compared to the contribution of sexual intercourse at $19.8 \%$. 


\section{DISCUSSION}

\subsection{Sexual Intercourse}

Based on Figure 3.1 illustrates the behavior of people with HIV/AIDS in Aceh Province related to sexual behavior that has a significant influence on HIV/AIDS transmission. The relationship is related to sexual intercourse with an official partner and even free sex is carried out as a result of the low frequency of sex with a legitimate partner and lack of sensitivity to the partner's health conditions related to the illness. The frequency of low sex with a legitimate partner is due to the HIV ( + ) status in question which causes reluctance of the couple to have sex. Besides that, only some of them use safeguards in the form of condoms during sexual intercourse to prevent transmission of HIV/AIDS. In additions, some people with HIV/AIDS have a history of sexually transmitted diseases.

The results of this study are in accordance with the opinion of KPA [2] in Wanda[8] that HIV can be transmitted through penetrative sex that is not protected. The risk of contracting this disease is higher if through vaginal sex although transmission through anal sex is reported to have a risk 10 times higher than vaginal sex. Having a history of sexually transmitted infections specifically related to wounds and duh (fluid coming out of the body) that is not treated, then have an average of 6-10 times higher the possibility of transmitting HIV through sexual intercourse. While transmitting HIV through oral sex has a risk low, but the risk can increase if there are sores/ulcers around the mouth when ejaculating.

Reinforced by the opinions of [9] that sexual intercourse has a very high risk of transmitting the HIV virus plus the possibility of ignorance partner on the prevention of HIV/ AIDS. Supported by Simanjuntak's research result (2010) that the presence of significant influence of risk factors influence the incidence of illicit sex HIV/AIDS in the city of Medan that says that the modes of transmission of HIV/AIDS through heterosexual intercourse by $51.3 \%$. The higher the sexual behavior, the place of prostitution, moral poverty and coupled with the habit of changing partners causing HIV transmission to be higher.

Sex without marriage (free sex) can occur because of the encouragement of sexuality to get pleasure or satisfaction only sexual organs. The more frequent sex, the greater the likelihood of contracting various diseases, especially if the relationship is carried out without safety and the virus easily enters the bloodstream of the sex partner if there are injuries to the genitals, will increase if the couple has a history of sexually transmitted diseases (PMS). Associated with the technique of having sex for couples who already have HIV/AIDS, the solution is to have sex using safeguards such as condoms. This use needs to be more socialized as a form of preventing HIV/AIDS.

Even without doing any research, risk factors for transmission through sex have an influence on the outbreak of HIV/AIDS directly. However, to strengthen this statement, an attempt is made to prove statistically. The analysis result shows that the contributing factor to the risk of sexual transmission of HIV / AIDS in the province is $19.8 \%$. In the end, HIV / AIDS does not know whether someone is young or old, Muslim or non-Muslim, married or not, educated or not, and rich or poor, and the Acehnese or other tribes. HIV / AIDS can only be prevented by avoiding doing activities that cause the onshore transmission factor. In this case, sex with a positive $(+)$ partner with HIV / AIDS should not be done. But for married couples, they have their own rules for sex with their partners who are HIV $(+)$, namely the use of condoms. This does not mean legalizing sex outside marriage. 


\subsection{The Use of contaminated syringes (injectable drugs)}

Based on Figure 3.2, the majority of respondents were drug users through syringes. Syringes alternately between other users. Viruses can enter through injury. Viruses that have entered the blood will be detected within a few weeks or more. Even so, it still has a great chance of transmitting to others through the blood. The inaction and unconsciousness of the transmission of the HIV/AIDS virus cause the extent of infection to other people. The use of IDUs with their own equipment will have a small possibility for the spread of the virus if the equipment is clean and sterile. It is also impossible that having personal equipment can avoid contracting the HIV virus. But the effects of the drug which can encourage users unknowingly having sex with an infected person even possibility though. This is one of the causes of being infected with the HIV virus. In principle, once related to someone who has been infected and even with equipment that has been infected it is also likely to be infected.

The results of this study are in line with Susilowati [11] research that there is a significant influence between the risk factors of the influence of the use of a contaminated syringe (injectable drugs) and the incidence of HIV/AIDS in the city of Semarang. Some of the reasons for drug users using shared syringe include the fact that it is difficult to find a new syringe, there is a fear of being caught by police raids, looking for practical use of drugs and reducing the burden of purchase, a state of confusion which results in not thinking. The results reinforced by Kaplan, Sallis, \& Patterson [12] in Lubis's research [13] suggested that misuse drugs through contaminated syringe significantly increase the incidence of HIV/AIDS.

The level of the possibility of contracting HIV/AIDS through syringes alternately for drug users is very high especially one of the users whose blood contains HIV. It is not only HIV disease that can be contagious if you use a syringe together, even diseases like Hepatitis B and Hepatic $\mathrm{C}$ will also be infected at once. Therefore, the chain of HIV transmission through injection drug users must be decided by strict law enforcement in addition to monitoring those who have been infected with this disease.

Although without doing research, risk factors through the use of contaminated syringe have an equally strong influence with risk factors for sexual intercourse in influencing the spread of HIV/AIDS directly. However, to strengthen that statement then made efforts to prove statistically. The analysis shows that the contribution of the contaminated syringe to the risk of HIV / AIDS transmission in Aceh province is $39.8 \%$. This is in line with the high number of drug cases in Aceh. Based on the results of this study, all parties need to be aware of cases of high rates of drug cases in the province of Aceh, moreover this case has an impact on cases of sexual intercourse without marriage (free sex) which then simultaneously contribute to increasing the risk of HIV/AIDS transmission in Aceh province.

\section{Conclusion}

Sexual intercourse affects the risk factors for HIV / AIDS in Aceh Province with a contribution amounting to $19,8 \%$. These risk actors include sex with an official partner and even free sex, a lack of knowledge about partner health, especially related to HIV/AIDS, lack of awareness in condom use and having a history of PMS. While the use of contaminated syringes (injectable drugs) has an effect on the risk factors for HIV/AIDS transmission in Aceh Province with a contribution of $39.8 \%$. These risk factors including the use of syringes alternately in drug even medication that is associated with the level of frequency in its use. 


\section{REFERENCES}

[1] Infodatin, "Infodatin AIDS," Pusat Data dan Informasi Kementerian Kesehatan RI, 2014. [Online]. Available: http://www.depkes.go.id/resources/download/pusdatin/infodatin/Infodatin AIDS.pdf.

[2] Komisi Penanggulangan Aids, "Strategi dan rencana aksi nasional 2015-2019," 2015.

[3] Sugiyono, Metode Penelitian Kuantitatif Kualitatif dan Kombinasi (Mixed Methods). Bandung: Alfabeta, 2016.

[4] D. Gujarati, Dasar-dasar ekonometrika. Jakarta: Erlangga, 2006.

[5] Ashari and B. Santosa, Analisis statistik dengan microsoft excel dan SPSS. Yogyakarta: Andi, 2005.

[6] F. Fahdhienie and Desvita, "Faktor-faktor yang berhubungan dengan pencegahan HIV/AIDS pada remaja komplek perumahan ajuen desa lam hasan kecamatan peukan bada kabupaten aceh besar tahun 2008," JUKEMA (Jurnal Kesehat. Masy. Aceh), vol. 1, no. 1, 2011.

[7] Redaksi, "Persentase jumlah umat islam berbagai daerah di indonesia," Sang Pencerah, 2014. [Online]. Available: https://sangpencerah.id/2014/12/persentase-jumlah-umatislam-berbagai/.

[8] Y. Wanda, "Pengetahuan, sikap dan perilaku mahasiswa angkatan 2011 fakultas kedokteran universitas syiah kuala tentang HIV/AIDS.," Universitas Syiah Kuala, Banda Aceh, 2012.

[9] W. Astuti and F. Rayasari, "Pengalaman seksual pasangan penderita HIV dalam mempertahankan status HIV negatif di RSPI prof. dr. sulianti saroso," Indones. J. Nurs. Pract., vol. 1, no. 2, pp. 32-43, 2017.

[10] E. Simanjuntak, “Analisis factor resiko penularan hiv/aids di kota Medan," J. Pembang. Mns., vol. 4, no. 12, pp. 1-8, 2010.

[11] T. Susilowati, "Faktor-faktor risiko yang berpengaruh terhadap kejadian HIV dan AIDS di semarang dan sekitarnya,” J. Komun. Kesehat., vol. 2, no. 1, pp. 1-16, 2011.

[12] R. M. Kaplan, J. F. Sallis, and T. L. ( Patterson, Health and human behavior. New York: McGraw-Hill, Inc., 1993.

[13] Z. Lubis, "Gambaran karakteristik individu dan faktor risiko terjadinya infeksi opportunistik pada penderita HIV/ AIDS di rumah sakit penyakit infeksi sulianti saroso tahun 2011.,"Universitas Indonesia, 2012. 